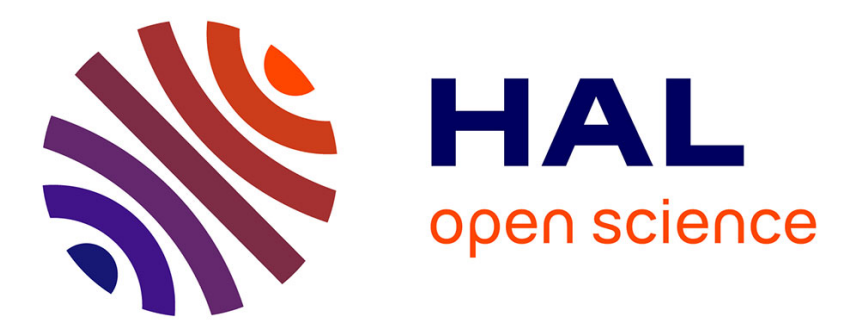

\title{
Paternal age: are the risks of infecundity and miscarriage higher when the man is aged 40 years or over?
}

Elise de La Rochebrochard, Patrick Thonneau

\section{- To cite this version:}

Elise de La Rochebrochard, Patrick Thonneau. Paternal age: are the risks of infecundity and miscarriage higher when the man is aged 40 years or over?. Epidemiology and Public Health = Revue d'Epidémiologie et de Santé Publique, 2005, 53 (Spec No 2), pp.47-55. 10.1016/s0398-7620(05)847674. hal-02270438

\section{HAL Id: hal-02270438 \\ https://hal.science/hal-02270438}

Submitted on 25 Aug 2019

HAL is a multi-disciplinary open access archive for the deposit and dissemination of scientific research documents, whether they are published or not. The documents may come from teaching and research institutions in France or abroad, or from public or private research centers.
L'archive ouverte pluridisciplinaire HAL, est destinée au dépôt et à la diffusion de documents scientifiques de niveau recherche, publiés ou non, émanant des établissements d'enseignement et de recherche français ou étrangers, des laboratoires publics ou privés. 
La Rochebrochard Elise (de), Thonneau Patrick, 2005, «Paternal age: are the risks of infecundity and miscarriage higher when the man is aged 40 years and over? », Revue d'Epidémiologie et de Santé Publique, 53, hors-série nII, p. 2S47-2S55. DOI: $10.1016 / \mathrm{s} 0398-7620(05) 84767-4$.

\section{Paternal age: are the risks of infecundity and miscarriage higher when the man is aged 40 years or over?}

FRENCH TITLE: Age paternel: y a t il une augmentation des risques d'infertilité et de fausse couche lorsque l'homme est âgé de plus de 40 ans? ${ }^{*}$

AUTHORS: Elise de La Rochebrochard, Patrick Thonneau

\section{DEPARTMENTS:}

INSERM, National Institute of Health and Medical Research, U569 "Epidemiology, Demography and Social sciences", IFR69, Le Kremlin-Bicêtre, France;

INED, National Institute for Demographic Studies, Paris, France; University Paris-Sud 11, Faculté de Médecine, Le Kremlin-Bicêtre, France

Groupe de recherche sur la fertilité humaine, Hôpital Paule de Viguier, 31059 Toulouse

CORRESPONDENCE: Elise de La Rochebrochard, Unité INSERM-INED 569, Hôpital de Bicêtre, 82, rue du Général Leclerc, 94276 Le Kremlin-Bicêtre Cedex France. Tel.: 0145-21-23-33, Fax: 01-45-21-20-75. E-mail: roche@ined.fr.

REPRINT REQUESTS: Elise de La Rochebrochard, Unité INSERM-INED 569, Hôpital de Bicêtre, 82, rue du Général Leclerc, 94276 Le Kremlin-Bicêtre Cedex France. E-mail: roche@ined.fr. 
RUNNING HEAD: Paternal age, infecundity and miscarriage

TITLE NOTE: This article relates to an original review published by the same authors in $J$ Androl [1]. Among other results, this paper presents results extracted from two original articles published by these authors [2, 3] 


\section{SUMMARY}

Background. Maternal age of 35 years or over is a well-known risk factor for human reproduction that has been extensively investigated by demographers and epidemiologists. However, the possibility of a paternal age effect has rarely been considered. We carried out review of the literature to investigate the effect of paternal age on the risks of infecundity and miscarriage.

Methods. We carried out a MEDLINE search and checked the exhaustiveness of our reference list.

Results. We identified 19 articles analysing the effect of paternal age. Epidemiological studies provided evidence that paternal age older than 35-40 years affects infecundity. However, the few studies based on data from assisted reproductive techniques (especially IVF with ovum donation) do not confirm this finding. All studies analysing the effect of paternal age on the risk of miscarriage showed an increased risk in men aged 35-40 years or over. Other studies have shown some evidence for a paternal age effect on late foetal deaths.

Conclusion. The risks of infecundity and miscarriage increase with paternal age. Two main hypotheses can be considered. First, these risks increase after the age of 35-40 years. However, a later paternal age effect (after 45-50 years) cannot be excluded. Second, due to the interaction of the ages of the two partners, the risks of infecundity and miscarriage may be higher when both partners are older (woman aged 35 years or over and man aged 40 years or over).

Key words: Paternal age. Infecundity. Miscarriage. 


\section{RESUME}

Position du problème. Un âge maternel $\geq 35$ ans est un facteur de risque bien connu de la reproduction humaine qui a été largement étudié par les démographes et les épidémiologistes. A l'opposé, la question d'un effet de l'âge paternel a été très peu soulevée. Notre objectif était d'effectuer une revue de la littérature analysant l'effet de l'âge paternel sur le risque d'infertilité et sur le risque de fausse couche.

Méthodes. Nous avons lancé une recherche dans MEDLINE et vérifié l'exhaustivité de notre liste de références. Nous avons trouvé 19 papiers analysant l'effet de l'âge paternel.

Résultats. Les études épidémiologiques analysant l'effet de l'âge paternel sur le risque d'infertilité apportent des éléments en faveur d'un effet de l'âge paternel après 35-40 ans. Cependant, les quelques études basées sur des données de l'assistance médicale à la procréation (en particulier les données sur les FIV avec don d'ovocytes) n'ont pas permis, pour l'instant, de confirmer cet effet de l'âge paternel. Tous les travaux ayant analysé l'effet de l'âge paternel sur le risque de fausses couches montrent une augmentation de ce risque chez les hommes $\geq 35-40$ ans. De plus, d'autres travaux apportent des éléments en faveur d'un effet de l'âge paternel sur la mortalité fœtale tardive.

Conclusion. Le risque d'infertilité et le risque de fausses couches augmentent avec l'âge paternel. Deux hypothèses majeures peuvent être tirées de la littérature. Premièrement, l'augmentation des risques survient chez les hommes âgés de plus de 35-40 ans. Cependant, un effet de l'âge paternel plus tardif (après 45-50 ans) ne peut être exclu. Deuxièmement, dû fait d'une interaction entre l'âge des deux partenaires, le risque d'infertilité et le risque de fausses couches pourraient être plus élevés lorsque les deux partenaires sont âgés (femme de plus de 35 ans et homme de plus de 40 ans).

Mots-clés: Age paternel. Infertilité. Fausse couche. 


\section{INTRODUCTION}

\section{Maternal age: an important risk factor that has been extensively investigated}

It is well known that age is a major risk factor for human reproduction [4-6]. The effect of maternal age on fecundity (the ability to reproduce) has been extensively investigated by demographers and epidemiologists. Fecundity is measured by time-topregnancy (TTP), which, for epidemiologists, is the time taken by a couple to obtain a pregnancy or, for demographers, the time taken to obtain a pregnancy leading to a live birth. TTP is a time variable that makes it possible to estimate the monthly probability of conceiving, which is called fecundability (or effective fecundability when considering only pregnancies leading to a live birth). TTP is a sensitive indicator of fecundity and can be studied retrospectively, with a long period of recall, using only a short questionnaire [7, 8]. For example, Larsen and Vaupel modelled variations in effective fecundability with maternal age in the Hutterites population by using a frailty model of event histories [9]. They estimated that effective fecundability decreases from $17.1 \%$ at 25 years of age to $9.9 \%$ at 35 years of age and then to $5.6 \%$ at 40 years of age.It is important to remember when considering the effect of maternal age on TTP that valid estimates are impossible if analysing TTPs of women who are pregnant or who have already given birth. The use of such fertile populations underestimates the effect of maternal age on fecundity, or can even inverse it (i.e. increasing fecundity with increasing maternal age), as sterile couples are excluded and less fecund couples are under-represented [10].

Other methods have been used to investigate the effect of maternal age on fecundity. Demographers have studied the risk of sterility (the inability to bear a child) by using historical data from populations not using birth control methods. These studies showed that the estimated risk of sterility increases from about 5-6\% between 20 and 24 years of age to about $16 \%$ at 30-35 years of age [11-13]. Epidemiologists used 
observations from artificial insemination programmes with donor sperm (AID) involving women with azoospermic husbands [14]. These data allowed the analysis of a maternal age effect without any effect of sexual activity or paternal confounding factors, which are highly correlated with maternal factors, especially age. The analysis showed that fecundity begins to slowly decrease at 30 years of age and then decreases more rapidly after the age of 35 years of age [14].

The consequences of maternal age on pregnancy outcome have also been investigated. Numerous studies have shown that the risk of adverse pregnancy outcomes, especially miscarriage and ectopic pregnancy, increases sharply with maternal age [15-18]. The analysis of all outcomes of pregnancies declared in Denmark between 1978 and 1992 (more than one million pregnancies) showed that the risk of miscarriage was estimated at $8.9 \%$ at $20-24$ years of age and at $74.7 \%$ when the woman is older than 45 years of age [17].

\section{Paternal age: first evidence of a paternal age effect}

Very few studies have studied the effects of paternal age on pregnancy outcome. Demographic studies provided the first evidence of a paternal age effect. Studies using large data sets of populations not practising birth control showed that, after controlling for maternal age, the probability of having a child decreases with increasing paternal age [1922]. Mineau and Trussell developed a model to analyse the effects on fertility of maternal age, paternal age and union duration [21]. They showed that maximum fertility rates occurred when the man was 30-34 years of age, and that these rates then slowly decreased with increasing age. At 50-59 years of age, the paternal age effect was stronger than the effect of a maternal age of 40-44 years.

Clinical studies on the effect of male age on sperm characteristics also provided evidence of a paternal age effect. Although results concerning the effect of age on human 
sperm are conflicting, a recent review has concluded that sperm volume and motility are altered, and that the proportion of normal sperm decreases in men between ages of 30 and 50 years [23].

We recently investigated the effect of paternal age on the risks of infecundity and miscarriage by analysing a large European dataset $[2,3]$. We concluded, in agreement with the existing studies, that paternal age had an effect on both risks [1].

Here, we carry out a review of the literature to investigate the effect of paternal age on the risks of infecundity and miscarriage. 


\section{MATERIALS AND METHODS}

We used MEDLINE to search for articles analysing the effects of paternal age on the risks of infecundity and miscarriage. This procedure has been described in detail elsewhere [1]. We checked the exhaustiveness of our search by crosschecking with related references (references cited in articles selected, PubMed related articles and our reference database). We identified 19 articles analysing the effect of paternal age on pregnancy outcome. Table I lists the 19 articles selected. 


\section{RESULTS}

Table II summarises the main characteristics of the 19 articles analysing paternal age effect. Ten articles looked at risk of infecundity with the other nine looking at risk of miscarriage. Seven of the studies on the risk of infecundity were epidemiological studies and four were based on assisted reproductive technologies (ART) data. For the risk of miscarriage, four articles were epidemiological studies and five were based on analysis of birth and foetal death certificates. Sixty-three percent of all articles were published in the last five years (1999-2003). Most articles (69\%) concluded that there was a paternal age effect on pregnancy outcome, but our subsequent analysis will show that not all studies were of equal quality.

We considered that two of the seven articles using epidemiological sources to analyse infecundity were particularly interesting because the studies used large datasets and included couples who had and couples who had not yet conceived, and because the studies controlled for maternal age. Our study on paternal age and infecundity was based on data from a European multicentre study in which women were retrospectively asked about their reproductive life [2]. We analysed, among 3287 couples, the risk of not having conceived after one year of trying after controlling for confounding factors. This showed that the risk of infecundity was higher among couples where the man was older than 40 years of age and the woman was aged 35 years or over (Figure 1a). Another study was based on a European dataset [24] and used prospective methods, which have recently been recognised as the gold standard for fecundity studies [25]. This study analysed the daily probability of conception, using data from 782 couples who were asked to note their daily sexual activity, using natural family planning methods to determine day of ovulation. It concluded that the daily probability of conception was reduced in couples composed of a woman aged 35-39 years and a man in his late thirties or older. It concluded that the daily 
probability of conception was reduced in couples where the woman was 35-39 years of age and the men was in his late thirties or older.

Five other epidemiological studies analysed the effect of paternal age on the risk of infecundity. One study showed an elevated risk of infecundity when the man is aged 35 years or over. However, the study was limited by a low number of observations and a two age class analysis [26]. The four other articles were based on populations of couples including a pregnant woman or of couples having already given birth. This excluded sterile couples and under-represented less fecund couples. Despite this limitation, the four articles showed some evidence of a paternal age effect: two articles showed a paternal age effect after controlling for maternal age $[27,28]$ but the validity of one of them was debatable because of a wrong age definition [29]; one showed a very weak paternal age effect [30]; and one showed no paternal age effect on fecundity [31].

There were four articles analysing the effect of paternal age on fecundity based on data from ART. Only one of these articles showed a paternal age effect. The three other articles used data from in vitro fertilisation (IVF) with an ovum donor. In these cases, the age of the ovum donor is not correlated with paternal age. The analysis of 558 cycles done at a French IVF centre showed a significant decrease in pregnancy rate when paternal age was greater than or equal to 39 years [32]. However, this paternal age effect was only observed if there were less than five donated oocytes. The two other articles on IVF with ovum donation did not show any paternal age effect, however the studies did not control for the number of donated oocytes [33, 34]. Similarly, in an analysis of sperm from 43 fathers and grandfathers, paternal age did not appear to affect the ability of spermatozoa to penetrate ova (HOP test) [35]. 
Four articles investigated the effect of paternal age on the risk of miscarriage. All four articles showed a paternal age effect. We analysed the outcomes of 3174 most recent pregnancies in the European multicentre study [2]. After controlling for maternal age and confounding factors, we found that the risk of miscarriage was higher when the man was aged 40 years or over. A very strong increase in the risk of miscarriage was observed in couples where the woman was aged 35 years or over and the man was aged 40 years or over (Figure 1b). The analysis of 1511 French women in semi-parametric models showed an increased risk of miscarriage when the man was aged 35 years or over [36]. This study showed that the paternal age effect was stronger when the woman was young. The two other articles showed a paternal age effect on risk of miscarriage, but these studies were limited by the low number of pregnancies observed, a two age class analysis or lack of maternal age effect [26, 37].

Five articles investigated the effect of paternal age on late foetal death (after 20 weeks of gestation). These studies comprised very large datasets based on birth and late foetal death certificates and gave only very limited information on confounding factors. Four studies showed a paternal age effect, especially after 35 years of age [38-41], with one showing no effect [42]. 


\section{DISCUSSION}

There are very few articles $(n=19)$ that have investigated the effect of paternal age on the risks of infecundity and miscarriage. However, analysis of all published articles showed that interest in paternal age effects on pregnancy outcome has increased in recent years: in the last five years, twelve articles (63\% of all articles found) studied a paternal age effect.

Epidemiological studies have shown that fecundity decreases as paternal age increases. It has been shown that restricting analysis to fertile couples (pregnant women or women who have already given birth) leads to an underestimation of the age effect or even an inverse age effect [10]. Thus, we were particularly interested in studies that did not select couples on the basis of their fertility. These studies, and the others to a lesser extent, showed a significant paternal age effect. Data from ART are complementary to epidemiological studies. ART data make it possible to analyse the age effect without any sexual activity effect. Furthermore, by analysing IVF with ovum donation, it is possible to analyse the age effect without the problems associated with paternal and maternal age being highly correlated. The ART data presented in this review did not provide clear evidence of a paternal age effect. However, these studies were very limited and need to be developed before firm conclusions can be drawn. All epidemiological studies that investigated the effect of paternal age on miscarriage concluded that the risk increased with paternal age. Register-based studies also showed some evidence of a paternal age effect on late foetal death.

We have concluded from these 19 articles that paternal age should be considered as a risk factor for infecundity and miscarriage. However, further research is required to describe this paternal age effect precisely. Environmental exposure may affect the male reproductive tract [43-45] and determining the possible role of environmental factors on 
the paternal age effect would be useful. The evidence on paternal age we present here leads to two main hypotheses.

First, articles that showed a paternal age effect showed that the risks of infecundity and miscarriage increase when the man is over 35 or 40 years of age. This age corresponds well with the age limits of 40 years for sperm donors [46, 47]. This limit was chosen by considering the risk of genetic anomalies [48] without considering the results of the articles reviewed here. Two of the reviewed articles showed a later paternal age effect occurring after 45 or 50 years of age $[27,37]$. Thus, further research is necessary to confirm that an effect occurs from 35-40 years of age.

Second, several articles showed that the paternal age effect is stronger when the female partner had reproductive risk factors, such as elevated age (over 35 years) or weak ovarian response (less than 5 oocytes) [2, 3, 24, 32, 41]. This suggests an interaction between paternal age and maternal factors. Our study (see Figure 1) showed that the risks of infecundity and miscarriage are particularly high in couples where the woman is aged 35 years or over and man is aged 40 years or over. A detailed prospective study on daily probabilities also came to the same conclusion. These studies suggested an interaction between paternal age and maternal age. However, two other articles gave contradictory results $[27,36]$. Thus, the hypothesis of an interaction between paternal age and maternal age needs to be confirmed. Studies analysing the causes of infertility have also shown an interaction between maternal and paternal factors. An analysis of 1686 French couples who consulted a practitioner following one year of infertility showed that both partners presented reproductive disorders in $39 \%$ of cases [49]. The authors concluded that this result confirms the notion that infecundity is essentially 'a couple's business'. Therefore, is age also 'a couple's business'? 
Infecundity may increase with paternal age because of alteration of sperm characteristics with increasing age. Indeed, fecundability varies with sperm characteristicssuch as concentration and morphology [50-52]. A recent review on the effect of male age on sperm characteristics concluded that semen volume decreases, sperm motility decreases and sperm morphology changes between the ages of 30 and 50 years [23]. Thus, the paternal age effect may be caused by sperm characteristics, and especially sperm morphology. Genetic defects may also explain the increased in risks of miscarriage and of infecundity with paternal age. Indeed, embryo and (early) foetal death are often caused by chromosomal aberration and genetic defects [53-56]. The effects of paternal age on the risk of foetal chromosomal aberration and genetic defects remain largely unknown. However, it has been shown that the risk of autosomal dominant diseases among live births increases when paternal age is over 40 years $[48,57,58]$. If paternal age affects the risk of genetic defects among live births, it probably also has an effect on foetuses.

In conclusion, maternal age over 35 years has long been known to be a major risk factor for reproduction. Our review of the literature on the effect of paternal age has shown that paternal age over 40 years should also be considered a risk factor. Moreover, couples in which the woman is over 35 years and the man is over 40 years may have a particularly high reproductive risk. 


\section{REFERENCES}

1. de La Rochebrochard E, McElreavey K, Thonneau P. Paternal age over 40 years: the 'amber light' in the reproductive life of men? J Androl 2003; 24: 459-65.

2. de La Rochebrochard E, Thonneau P. Paternal age and maternal age are risk factors for miscarriage; results of a multicentre European study. Hum Reprod 2002; 17 : 1649-56.

3. de La Rochebrochard E, Thonneau P. Paternal age over 40 years: an important risk factor for infertility. Am J Obstet Gynecol 2003; 189: 901-5.

4. Tietze C. Reproductive span and rate of reproduction among Hutterite women. Fertil Steril 1957; 8: 89-97.

5. van Balen F, Verdurmen JE, Ketting E. Age, the desire to have a child and cumulative pregnancy rate. Hum Reprod 1997; 12: 623-7.

6. Breart G. Delayed childbearing. Eur J Obstet Gynecol Reprod Biol 1997; 75: 71-3.

7. Baird DD, Weinberg CR, Rowland AS. Reporting errors in time-to-pregnancy data collected with a short questionnaire. Impact on power and estimation of fecundability ratios. Am J Epidemiol 1991; 133: 1282-90.

8. Joffe M, Villard L, Li Z, Plowman R, Vessey M. A time to pregnancy questionnaire designed for long term recall: validity in Oxford, England. J Epidemiol Community Health 1995; 49: 314-9.

9. Larsen U, Vaupel JW. Hutterite fecundability by age and parity: strategies for frailty modeling of event histories. Demography 1993; 30: 81-102.

10. Juul S, Keiding N, Tvede M, European Infertility and Subfecundity Study Group. Retrospectively sampled time-to-pregnancy data may make age-decreasing fecundity look increasing. Epidemiology 2000; 11: 717-9.

11. Henry L. Some data on natural fertility. Eugen Q 1961; 8: 81-91. 
12. Leridon H. Human Fertility. The basic components. Chicago - London: The University of Chicago Press, 1977.

13. Menken J, Trussell J, Larsen U. Age and infertility. Science 1986; 233: 1389-94.

14. Schwartz D, Mayaux MJ. Female fecundity as a function of age: results of artificial insemination in 2193 nulliparous women with azoospermic husbands. Federation CECOS. N Engl J Med 1982; 306: 404-6.

15. Bouyer J, Coste J, Shojaei $\mathrm{T}$, et al. Risk factors for ectopic pregnancy: a comprehensive analysis based on a large case-control, population-based study in France. Am J Epidemiol 2003; 157: 185-94.

16. Wood JW, Weinstein M. A model of age-specific fecundability. Popul Stud 1988; 42: 85-113.

17. Nybo Andersen AM, Wohlfahrt J, Christens P, Olsen J, Melbye M. Maternal age and fetal loss: population based register linkage study. BMJ 2000; 320: 1708-12.

18. Leridon H. Facts and artifacts in the study of intra-uterine mortality: a reconsideration from pregnancy outcome. Popul Stud 1976; 30: 319-35.

19. Anderson BA. Male age and infertility. Results from Ireland prior to 1911. Popul Index 1975; 41: 561-7.

20. Goldman N, Montgomery M. Fecundability and husband's age. Soc Biol 1989; 36: 146-66.

21. Mineau GP, Trussell J. A specification of marital fertility by parents' age, age at marriage and marital duration. Demography 1982; 19: 335-50.

22. Strassmann BI, Warner JH. Predictors of fecundability and conception waits among the Dogon of Mali. Am J Phys Anthropol 1998; 105: 167-84.

23. Kidd SA, Eskenazi B, Wyrobek AJ. Effects of male age on semen quality and fertility: a review of the literature. Fertil Steril 2001; 75: 237-48. 
24. Dunson DB, Colombo B, Baird DD. Changes with age in the level and duration of fertility in the menstrual cycle. Hum Reprod 2002; 17: 1399-403.

25. Tingen C, Stanford JB, Dunson DB. Methodologic and statistical approaches to studying human fertility and environmental exposure. Environ Health Perspect 2004; 112: 87-93.

26. Ford JH, MacCormac L, Hiller J. PALS (pregnancy and lifestyle study): association between occupational and environmental exposure to chemicals and reproductive outcome. Mutat Res 1994; 313: 153-64.

27. Hassan MA, Killick SR. Effect of male age on fertility: evidence for the decline in male fertility with increasing age. Fertil Steril 2003; 79: 1520-7.

28. Ford WC, North K, Taylor H, Farrow A, Hull MG, Golding J. Increasing paternal age is associated with delayed conception in a large population of fertile couples: evidence for declining fecundity in older men. The ALSPAC Study Team (Avon Longitudinal Study of Pregnancy and Childhood). Hum Reprod 2000; 15: 1703-8.

29. Sallmen M, Luukkonen R. Is the observed association increasing paternal age and delayed conception an artefact? Hum Reprod 2001; 16: 2027-8.

30. Olsen J. Subfecundity according to the age of the mother and the father. Dan Med Bull 1990; 37: 281-2.

31. Joffe M, Li Z. Male and female factors in fertility. Am J Epidemiol 1994; 140: 921 9.

32. Watanabe Y, Cornet D, Merviel P, Mandelbaum J, Antoine JM, Uzan S. Influence of husband's age on outcome of a shared oocyte donation program. Fertil Steril 2000; 74: S78-S9.

33. Gallardo E, Simon C, Levy M, Guanes PP, Remohi J, Pellicer A. Effect of age on sperm fertility potential: oocyte donation as a model. Fertil Steril 1996; 66: 260-4. 
34. Paulson RJ, Milligan RC, Sokol RZ. The lack of influence of age on male fertility. Am J Obstet Gynecol 2001; 184: 818-22; discussion 22-4.

35. Nieschlag E, Lammers U, Freischem CW, Langer K, Wickings EJ. Reproductive functions in young fathers and grandfathers. J Clin Endocrinol Metab 1982; 55: $676-81$

36. Slama R, Werwatz A, Boutou O, Ducot B, Spira A, Hardle W. Does male age affect the risk of spontaneous abortion? An approach using semiparametric regression. Am J Epidemiol 2003; 157: 815-24.

37. al-Ansary LA, Babay ZA. Risk factors for spontaneous abortion: a preliminary study on Saudi women. J R Soc Health 1994; 114: 188-93.

38. Selvin S, Garfinkel J. Paternal age, maternal age and birth order and the risk of a fetal loss. Hum Biol 1976; 48: 223-30.

39. Rychtarikova J, Gourbin C, Wunsch G. Paternal age and child death: the stillbirth case. European Journal of Population 2004; 20: 23-33.

40. Gourbin C, Wunsch G. Paternal age and infant mortality. Genus 1999; LV: 61-72.

41. Astolfi P, De Pasquale A, Zonta LA. Late paternity and stillbirth risk. Hum Reprod 2004; 19: 2497-501.

42. Resseguie LJ. Paternal age, stillbirths and mutation. Ann Hum Genet 1976; 40: 213-9.

43. Auger J, Kunstmann JM, Czyglik F, Jouannet P. Decline in semen quality among fertile men in Paris during the past 20 years. N Engl J Med 1995; 332: 281-5.

44. Savitz DA, Sonnenfeld NL, Olshan AF. Review of epidemiologic studies of paternal occupational exposure and spontaneous abortion. Am J Ind Med 1994; 25 : $361-83$. 
45. Huyghe E, Matsuda T, Thonneau P. Increasing incidence of testicular cancer worldwide: a review. J Urol 2003; 170: 5-11.

46. British Andrology Society (BAS). British Andrology Society guidelines for the screening of semen donors for donor insemination (1999). Hum Reprod 1999; 14: 1823-6.

47. American Society for Reproductive Medicine (ASRM). Guidelines for gamete and embryo donation. Fertil Steril 1998; 70: 1S-13S.

48. Bordson BL, Leonardo VS. The appropriate upper age limit for semen donors: a review of the genetic effects of paternal age. Fertil Steril 1991; 56: 397-401.

49. Thonneau P, Marchand S, Tallec A, et al. Incidence and main causes of infertility in a resident population $(1,850,000)$ of three French regions (1988-1989). Hum Reprod 1991; 6: 811-6.

50. Bonde JP, Ernst E, Jensen TK, et al. Relation between semen quality and fertility: a population-based study of 430 first-pregnancy planners. Lancet 1998; 352: 1172-7.

51. Slama R, Eustache F, Ducot B, et al. Time to pregnancy and semen parameters: a cross-sectional study among fertile couples from four European cities. Hum Reprod 2002; 17: 503-15.

52. Zinaman MJ, Brown CC, Selevan SG, Clegg ED. Semen quality and human fertility: a prospective study with healthy couples. J Androl 2000; 21: 145-53.

53. Boue A, Boue J, Gropp A. Cytogenetics of pregnancy wastage. Adv Hum Genet 1985; 14: 1-57.

54. Jacobs PA. The role of chromosome abnormalities in reproductive failure. Reprod Nutr Dev 1990; Suppl: 63s-74s. 
55. Cowchock FS, Gibas Z, Jackson LG. Chromosome errors as a cause of spontaneous abortion: the relative importance of maternal age and obstetric history. Fertil Steril 1993; 59: 1011-4.

56. Wood J. Fetal loss. In: Dynamics of human reproduction, biology, biometry, demography. New York: Adline de Gruyter, 1994: 239-77.

57. Friedman JM. Genetic disease in the offspring of older fathers. Obstet Gynecol 1981; 57: 745-9.

58. American College of Obstetricians and Gynecologists (ACOG) Committee. ACOG committee opinion. Advanced paternal age: risks to the fetus. Number 189, October 1997. Committee on Genetics. Int J Gynaecol Obstet 1997; 59: 271-2. 
Table I. Studies on the effect of paternal age on the risks of infecundity and miscarriage

\begin{tabular}{|c|c|c|c|c|}
\hline Reference & Population studied & Reproductive outcome & Paternal age classes ${ }^{*}$ & $\begin{array}{c}\text { Paternal age } \\
\text { effect? }\end{array}$ \\
\hline \multicolumn{5}{|c|}{ INFERTILITY } \\
\hline $\begin{array}{l}\text { La Rochebrochard and } \\
\text { Thonneau, } 2003\end{array}$ & 3,287 women trying to conceive & Infertility (12 months) & $<30 / 30-34 / 35-39 / \geq 40$ & +++ \\
\hline Hassan et Killick, 2003 & 2,112 pregnancies & Time to pregnancy & $\leq 25$ (ref)/ 26-30/31-35 / 36-40 / 41-45/ $\geq 46$ & +++ \\
\hline Dunson et al., 2002 & $\begin{array}{l}782 \text { couples using natural family planning } \\
\text { methods }\end{array}$ & $\begin{array}{l}\text { Probabilities of pregnancy on various } \\
\text { days of the menstrual cycle }\end{array}$ & $19-26 / 27-29 / 30-34 / 35-39 / \geq 40$ & +++ \\
\hline Paulson et al., 2001 & 558 IVF cycles with ovum donation & Clinical pregnancy & $<38 / 38-41 / 42-46 />46$ & - \\
\hline Watanabe et al., 2000 & 288 IVF cycles with ovum donation & Clinical pregnancy & $<39$ (ref) $/ \geq 39$ & + \\
\hline Ford et al., 2000 & 8,515 planned pregnancies & Infertility (6 and 12 months) & $\leq 24$ (ref) / 25-29/30-34 / 35-39/ $\geq 40$ & ++ \\
\hline Gallardo et al., 1996 & 316 IVF cycles with ovum donation & Clinical pregnancy & $31-40 / 41-50 / \geq 51$ & - \\
\hline Joffe and Li, 1994 & $\begin{array}{l}2,576 \text { men aged } 33 \text { years who had } \\
\text { fathered a child }\end{array}$ & Time to pregnancy & $<30$ (ref) / 30-33 & - \\
\hline Ford et al., 1994 & 585 couples trying to conceive & Infertility (9 months) & $<35$ (ref) $/ \geq 35$ & ++ \\
\hline Olsen, 1990 & 10,886 pregnancies & Infertility (12 months) & $15-19$ (ref)/ $20-24 / 25-29 / 30-34 / 35-39 / \geq 40$ & $-/+$ \\
\hline Nieschlag et al., 1982 & 43 men who had fathered a child & Ovum penetration (HOP test) & $24-37$ (ref) / 60-88 & - \\
\hline \multicolumn{5}{|c|}{ MISCARRIAGE } \\
\hline Astolfi et al., 2004 & 3.6 million birth and foetal death certificates & Late spontaneous abortion & - & +++ \\
\hline Rychtarikova et al., 2004 & 598,157 birth and foetal death certificates & Late spontaneous abortion & $15-19 / 20-24(\mathrm{ref}) / 25-29 / 30-34 / 35-39 / 40-44$ & ++ \\
\hline Slama et al., 2003 & 1,151 women having 2,414 pregnancies & Miscarriage & $<35 / \geq 35$ & +++ \\
\hline $\begin{array}{l}\text { de La Rochebrochard and } \\
\text { Thonneau, } 2002\end{array}$ & 3,174 planned pregnancies & Miscarriage & $20-29$ (ref) / 30-34 / 35-39/ $\geq 40$ & +++ \\
\hline Gourbin and Wunsch, 1999 & 498,122 birth and foetal death certificates & Late spontaneous abortion & $25-34 / 35-44$ & + \\
\hline al-Ansary and Babay, 1994 & $\begin{array}{l}\text { Hospital patients: } 226 \text { miscarriages and } \\
226 \text { controls }\end{array}$ & Miscarriage & $<30$ (ref) / 30-34 / 35-39 / 40-49 / $\geq 50$ & ++ \\
\hline Ford et al., 1994 & 484 planned pregnancies & Miscarriage (first trimester) & $<35$ (ref) $/ \geq 35$ & ++ \\
\hline Selvin and Garfinkel, 1976 & 1.5 million birth and fetal death certificates & Late spontaneous abortion & - & + \\
\hline Resseguie, 1976 & Birth and fetal death certificates & Late spontaneous abortion & - & - \\
\hline
\end{tabular}

*: In case of multivariate regression analysis, the reference class is indicated by '(ref)'. 
Table II. Description of articles analysing the effect of paternal age ( $n=19$ articles)

\begin{tabular}{lcc}
\hline & $\begin{array}{c}\text { Number of } \\
\text { articles }\end{array}$ & $\begin{array}{c}\text { Per cent of } \\
\text { articles }\end{array}$ \\
\hline Outcome analysed & & \\
$\quad$ Infecundity & 10 & $53 \%$ \\
Miscarriage & 8 & $42 \%$ \\
Infecundity and miscarriage & 1 & $5 \%$ \\
Year of publication & & \\
$\leq 1988$ & 3 & $16 \%$ \\
$1989-1993$ & 0 & $0 \%$ \\
$1994-1998$ & 4 & $21 \%$ \\
$1999-2003$ & 12 & $63 \%$ \\
Data source & & \\
epidemiological study & & $53 \%$ \\
administrative source & 10 & $26 \%$ \\
data from ART & 5 & $21 \%$ \\
Conclusion on paternal age effect & 4 & \\
an effect & & $5 \% \%$ \\
a weak effect & & $26 \%$ \\
No effect & 13 & \\
\hline
\end{tabular}


Figure 1. Effect of paternal age on infecundity and miscarriage

in logistic regression (adjusted Odds Ratio [95\% Confidence Interval])

\section{a. Risk of infecundity}

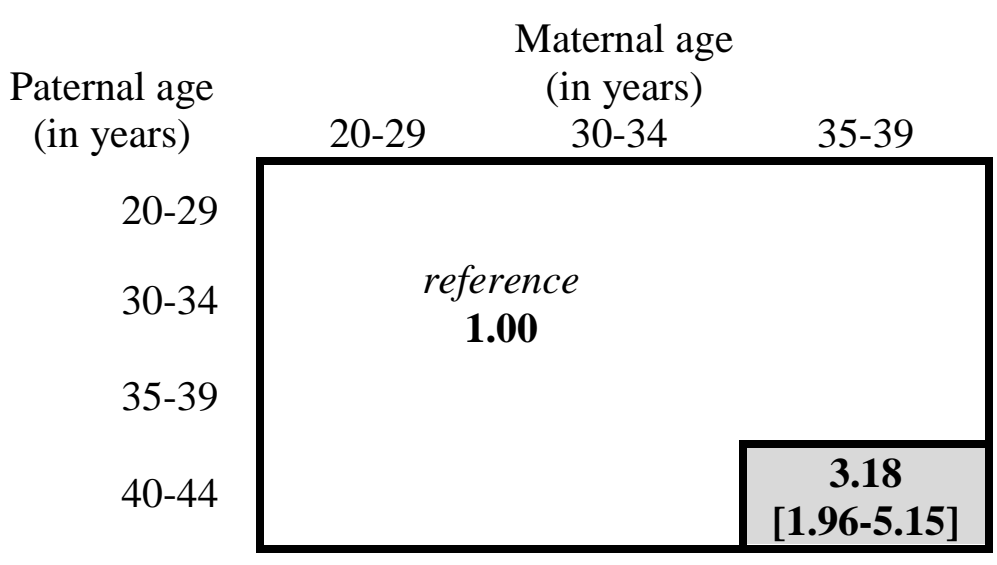

b. Risk of miscarriage

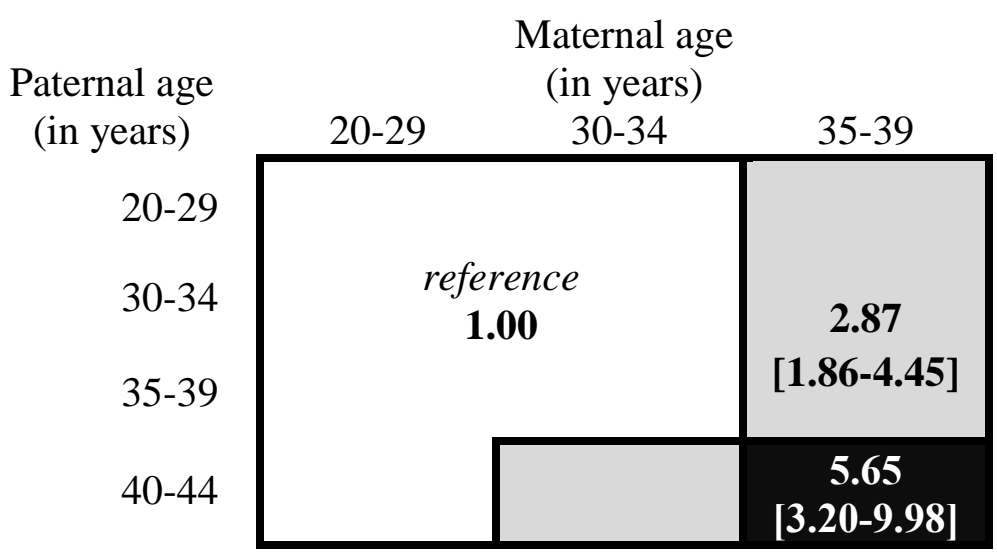

Legend: comparison of risk zones

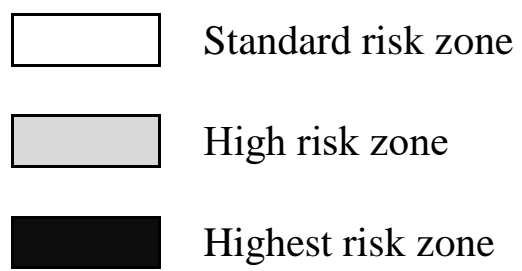

Note: This figure is a schematic representation of the results presented in $[2,3]$ 